\title{
Effects of aging on abdominal wall healing in rats ${ }^{1}$
}

\section{Efeitos do envelhecimento na cicatrização da parede abdominal, em ratos}

\author{
Maria de Lourdes Pessole Biondo-Simões ${ }^{2}$, Oreste Terranova ${ }^{3}$, Sergio Ossamu Ioshii ${ }^{4}$, Karin Soldatelli Borsato ${ }^{5}$, Janaína \\ Weingärtner $^{6}$, Gustavo Nogueira ${ }^{6}$, Patrícia Longhi ${ }^{6}$
}

1. Research carried out in the Discipline of Operative Technique and Experimental Surgery, Medical School of the Pontifical Catholic University of Paraná (PUCPR)

2. Professor of the Discipline of Operative Technique and Experimental Surgery, Medical School of the Pontifical Catholic University of Paraná (PUCPR) and Federal University of Paraná (UFPR).

3. Professor of the Geriatric Surgery of the Università degli Studi di Padova - Italy

4. Associate Professor of the Discipline of Experimental Pathology (PUCPR and UFPR)

5. Professor of the Laboratory of Destructive Assays (PUCPR)

6. Scientific Initiation Studens.

\begin{abstract}
Purpose: The aim of this study was to assess abdominal wall healing in old and young adult rats. Methods: On average, young animals were 110 days old and old animals were 762 days old. A $4.0 \mathrm{~cm}$ median laparotomy was performed under anesthesia, followed by laparorrhaphy on two synthesis planes, i.e. peritoneum-muscle-aponeurosis and skin, using continuous 5.0 nylon sutures. The animals were evaluated on the $3^{\text {rd }}, 7^{\text {th }}, 14^{\text {th }}$ and $21^{\text {st }}$ postoperative days. The resistance of the two planes was studied separately and a histopathologic analysis was performed on sections stained with hematoxylineosin and Sirius Red. Immunohistochemical analysis was also carried out using PCNA, LCA and CD34. Results: The skin scars gained resistance in a similar manner at the initial time points, but those of young rats were more resistant on the $21^{\text {st }}$ day $(\mathrm{p}=0.0029)$. Total and type III collagen content was similar in the two groups and type I collagen content was higher in young animals on the $14^{\text {th }}$ day. Inflammatory cell infiltration was more marked in the skin wounds of young animals on the $3^{\text {rd }}$ day $(\mathrm{p}=0.0190)$. Reepithelialization was similar and angiogenesis was more intense in the skin wounds of young animals on the $14^{\text {th }}$ day $(\mathrm{p}=0.0062)$. The peritoneum-muscle-aponeurosis wounds gained similar resistance during the early phases, but were more resistant on the $14^{\text {th }}$ day $(p=0.0005)$ and on the $21^{\text {st }}$ day $(p=0.0023)$ in old rats Collagen concentration was higher in the wounds of old animals on the $3^{\text {rd }}$ day $(\mathrm{p}=0.0112)$ and in the wounds of young animals on the $21^{\text {st }}$ day $(p=0.0348)$. The inflammatory reaction was more intense in the wounds of old animals on the $3^{\text {rd }}$ day $(p=0.0060)$ and angiogenesis was more intense on the $14^{\text {th }}$ day (0.0432). Conclusion: Although there are some differences in the healing course between young and old animals, age, of itself, does not impair the healing of abdominal wall wounds in rats.
\end{abstract}

Key words: Wound healing. Aging. Abdominal wall. Rats.

\section{RESUMO}

Objetivo: Estudar a cicatrização da parede abdominal em ratos adultos jovens e velhos. Métodos: Os ratos adultos jovens tinham em média 110 dias de idade e os velhos 762 dias. Uma laparotomia mediana de 4,0 cm foi feita sob anestesia, seguida de laparorrafia com 2 planos de síntese, isto é, peritônio-músculo-aponevrose e pele, com síntese contínua de fio de náilon 5.0. Os animais foram avaliados com 3, 7, 14 e 21 dias de pós-operatório. A resistência dos dois planos foi avaliada separadamente e a análise histológica feita em cortes preparados pela Hematoxilina-eosina e Sirius red. Análise imunohistoquímica foi realizada empregando PCNA, LCA and CD34. Resultados: A cicatriz da pele ganhou resistência de modo similar nos tempos iniciais, mas as dos animais jovens foram mais resistentes no $21^{\circ} \mathrm{dia}(\mathrm{p}=0.0029)$. A densidade de colágeno total e tipo III foi similar nos dois grupos, porém o colágeno tipo I mostrou-se mais denso nas cicatrizes dos animais jovens no $14 .^{\circ}$ dia. O infiltrado de células inflamatórias foi maior nas cicatrizes dos animais jovens no $3 .^{\circ}$ dia $(p=0.0190)$. A reepitelização foi similar e a angiogênese foi mais intensa na pele dos animais jovens, no $14{ }^{\circ}$ dia $(p=0.0062)$. O plano peritônio-músculo-aponevrótico ganhou similar resistência durante as fases iniciais, porém foi mais resistente no $14 .^{\circ}$ dia $(\mathrm{p}=0.0005)$ e no $21 .^{\circ}$ dia $(\mathrm{p}=0.0023)$ nos animais velhos. A densidade de colágeno foi maior nas paredes dos animais velhos no $3 .^{\circ} \mathrm{dia}(\mathrm{p}=0.0112)$ e nos animais jovens no $21 .^{\circ}$ dia $(\mathrm{p}=0.0348)$. A reação inflamatória foi mais intensa nas paredes dos animais velhos no $3 .^{\circ}$ dia $(p=0.0060)$ e a angiogênese mais intensa no $14 .^{\circ}$ dia (0.0432). Conclusão: Embora existam diferenças na evolução do processo de cicatrização de jovens e velhos, a idade por si só, não prejudica a cicatrização da parede abdominal, em ratos.

Descritores: Cicatrização de feridas. Envelhecimento.Parede abdominal. Ratos 


\section{Introduction}

Medical advances have led to a better understanding of the health-disease diad and technological advances have permitted more precise diagnoses and more efficient treatments. In addition, the work of public health services and educational programs directed at the population have contributed to the prevention of disease. As a result, health conditions have improved and man's longevity has increased $^{1,2}$ together with the number of elderly persons in hospitals ${ }^{3}$.

When elderly patients are submitted to surgical procedures, physicians and relatives are concerned about the possible complications. Some investigators have stated that age is not a factor predisposing to complications ${ }^{4}$, whereas others have demonstrated that the complications occurring in older patients definitely lead to higher morbidity and mortality rates ${ }^{3,5-9}$.

Mendoza Jr et al ${ }^{10}$ howed that elderly patients had a 5fold higher chance to experience wall dehiscence than young patients ${ }^{10}$. Riou et a ${ }^{11}$ reported 31 cases of wall dehiscence among 2761 patients and compared these patients to 38 other ones who had been submitted to similar operations. Among the risk factors, they cited age older than 65 years.

Several studies have reported delayed reepithelialization in the elderly ${ }^{12,13}$ and a lower proliferative response of keratinocytes ${ }^{14}$. Highly controversial descriptions have been published concerning collagen synthesis and concentration in surgical wounds. Reed et $\mathrm{al}^{15}$ reported reduced collagen I in mice and Aschcroft et $\mathrm{al}^{16}$ reported a reduced deposition of collagen III and collagen I. Holt et al (1992) reported a similar accumulation of hydroxyproline and DNA, with no difference in collagen accumulation, among elderly individuals ${ }^{13}$. Swift et $\mathrm{al}^{17}$ studied and compared healing in young and old mice and concluded that healing was delayed in old animals due to a lower synthesis rate.

Cristofallo and Pignolo ${ }^{18}$ showed that senescent fibroblasts are unable to respond to mitogenic stimuli in vitro, whereas Fredland et al ${ }^{19}$ found no evidence that age led to a decline in collagen secretion by human fibroblasts. Kletsas et $\mathrm{al}^{20}$ again stated that there is no evidence of an age-dependent decline in the response of human fibroblasts to several growth factors such as epithelial growth factor (EGF), tumor necrosis factor alpha (TNF-a) and plateletderived growth factor (PDGF). According to these authors, the ability to synthesize was maintained and that the changes observed might depend on systemic factors such as altered levels of the hormones that regulate homeostasis in general.

It is clear that there is no consensus at the clinical or experimental level, a fact possibly due to the poor experimental design of human studies, to the lack of ideal subjects free from other diseases, and to inappropriate studies using animal models.

Thus, the objective of the present study was to monitor abdominal wall wound healing in young adult rats and compare it to healing in old rats.

\section{Methods}

The study was conducted according to the Federal Law 6638 and according to the recommendations of the Brazilian College of Animal Experimentation, an institution affiliated with the International Council for Laboratory Animal Science, and was approved by the Animal Research Ethics Committee of the Pontifical Catholic University of Paraná (PUCPR).

Fifty-six male Wistar-TECPAR rats (Rattus norvegicus albinus) were divided into two groups of 28 animals each, i.e., a group of young rats aged 100 to 113 days and weighing 185 to $220 \mathrm{~g}$ and a group of old rats aged 750 to 776 days and weighing 270 to $380 \mathrm{~g}$.

The animals were housed in appropriate cages in the Laboratory of Animals of PUCPR under natural light/dark conditions and humidity and with controlled temperature kept at $20 \pm 2^{\circ} \mathrm{C}$. The animals had free access to rat chow and water throughout the experiment.

Under anesthesia by ethyl ether inhalation, the animal's abdomen was shaved and disinfected with polyvinylpyrrolidone-iodine. A median four centimeters laparotomy was performed, followed by laparorrhaphy on two synthesis planes, the peritoneum-muscle-aponeurosis (PMA) and the skin, using continuous 5.0 nylon sutures. After recovery from anesthesia, the animals were returned to their cages.

Seven animals per group were sacrificed by excess ethyl ether inhalation by drawing lots on the $3^{\text {rd }}, 7^{\text {th }}, 14^{\text {th }}$ and $21^{\text {st }}$ postoperative days and submitted to autopsy for the detection of possible faulty repair along the synthesis line. The skin wound was then resected together with adjacent skin $2.0 \mathrm{~cm}$ above and below its limits and $4.0 \mathrm{~cm}$ laterally on the right and on the left. Three $1.0 \mathrm{~cm}$ fragments were obtained from this piece, discarding $0.5 \mathrm{~cm}$ above and below the wound. The same procedure was followed for the PMA plane, from which 3 fragments were also obtained. The central skin and PMA fragments were stretched on filter paper and placed in flasks containing physiological saline. The fragments were then immediately tested for tensile strength in an EMIC® traction machine (Laboratory of Destructive Analyses, PUCPR). The maximum force was considered to be the greatest force or load applied to the specimens until its rupture. The force was always applied perpendicular to the wound in an attempt to separate its margins. The upper and lower fragment of the skin and of the PMA plane were submitted to histopathological study. After embedding, 4-mm sections were obtained and slides containing 3 sections each were prepared. The sections were submitted to 5 types of staining: hematoxylin-eosin, histochemical Sirius red staining and immunohistochemical staining with anti-common leucocyte antigen (LCA) antibody, anti-cell proliferation nuclear antigen (PCNA) primary antibody, and anti-CD 34 antibody. We assessed general aspects, collagen deposition, inflammatory reaction, cell proliferation, and neovascularization.

Data were analyzed statistically using the chi-square test for $2 \times 2$ tables. When restrictions to this test were present, the Fischer exact test was used. The Student $t$-test was used for comparison. When the results did not fit a Gaussian curve, the Mann-Whitney test was used. The level 
of significance was set at $\mathrm{p}<0.05$ for all tests.

\section{Results}

Material from two young rats and from one old rat was lost.

\section{Macroscopic analysis}

Macroscopic analysis of the skin wound showed partial dehiscence in one wound from a young animal and in one wound from an old animal on the $3^{\text {rd }}$ day. On the $14^{\text {th }}$ day, three wounds from the old group and one from the young group showed partial dehiscence $(p=0.2797)$. On the $7^{\text {th }}$ and $21^{\text {st }}$ day all wounds were intact.

One partial dehiscence of the PMA scar was observed in the old group on the $14^{\text {th }}$ day $(\mathrm{p}=0.5000)$. On the $21^{\text {st }}$ day there were three dehiscences in old rats and two in young rats $(\mathrm{p}=0.6082)$.

\section{Scar resistance}

The tensile strength test showed that the scars did not offer resistance on the $3^{\text {rd }}$ day, being held together by the suture. The gain in resistance up to the $7^{\text {th }}$ day was nonsignificant, with only one wound in the young group and one in the old group withstanding some tension. The scars gained significant resistance, which was similar in the two groups, on the $14^{\text {th }}$ day $(\mathrm{p}=0.1625)$ and on the $21^{\text {st }}$ day, with the skin scars of young rats being more resistant than those of old rats $(p=0.0029)$. PMA scars did not show resistance on the $3^{\text {rd }}$ day, being held together by the sutures. They showed some resistance on the $7^{\text {th }}$ day, with no significant difference between young and old animals. On the 14th day there was more resistance in the scars of old animals $(\mathrm{p}=0.0005)$, the same occurring on the $21^{\text {st }}$ day $(p=0.0023)$.

\section{Microscopic analysis}

The general microscopic findings were similar in the two groups.

On the $3^{\text {rd }}$ day, the skin scars of both groups showed solution of continuity of epithelial tissue and the wounds presented a fibrin-leukocyte crust on the surface. Marginal reepithelialization was observed. An inflammatory cell infiltrate was observed below, with a predominance of polymorphonuclear cells, macrophages and mast cells and with scarce granulation tissue. The blood vessels along the margins of the lesion were greatly dilated.

On the $7^{\text {th }}$ day, three of the seven wounds of young animals and five of the seven wounds of old animals were completely reepithelialized (0.0942). An inflammatory cell infiltrate and abundant granulation tissue were observed below. On the $14^{\text {th }}$ day all wounds were completely reepithelialized. No skin adnexa were observed and the inflammatory reaction was scarce. On the $21^{\text {st }}$ day the epithelium was completely reconstituted and skin adnexa, mainly hair follicles, were observed, with a minimal inflammatory reaction.
PMA wounds presented solution of continuity in both young and old animals at all four time points studied. On the $3^{\text {rd }}$ day there was an inflammatory cell infiltrate and scarce granulation tissue. On the $7^{\text {th }}$ day there was abundant granulation tissue, as well as fibroblasts and new vessels. On the $14^{\text {th }}$ day the inflammatory reaction was of the acutechronic type and there was abundant granulation tissue. Large amounts of collagen were present in the inner and outer margins of the wound. On the $21^{\text {st }}$ day the inflammatory reaction was less intense and larger amounts of collagen were observed along the margins of the wound.

The inflammatory reaction was quantified by counting the inflammatory cells labeled with the anti-leucocyte antigen common in the skin and PMA scars.

On the $3^{\text {rd }}$ day there was a greater concentration of inflammatory cells in the skin scars of young animals $(p=0.0190)$, whereas no significant differences were observed between groups at the remaining time points. In the PMA scars the amount of inflammatory cells was higher in old animals on the $3^{\text {rd }}$ day $(\mathrm{p}=0.0060)$, whereas similar amounts were observed in the two groups at the remaining time points (Figure 1 and 2). At later times, it was possible to identify a large number of mast cells and foreign body giant cells (Figure 3). Reepithelialization was assessed by counting PCNA-positive and -negative nuclei, with no significant differences between groups $\left(\mathrm{p}_{3}=0.1343\right.$, $\left.\mathrm{p}_{7}=0.0622, \mathrm{p}_{14}=0.4045, \mathrm{p}_{21}=0.1138\right)$.

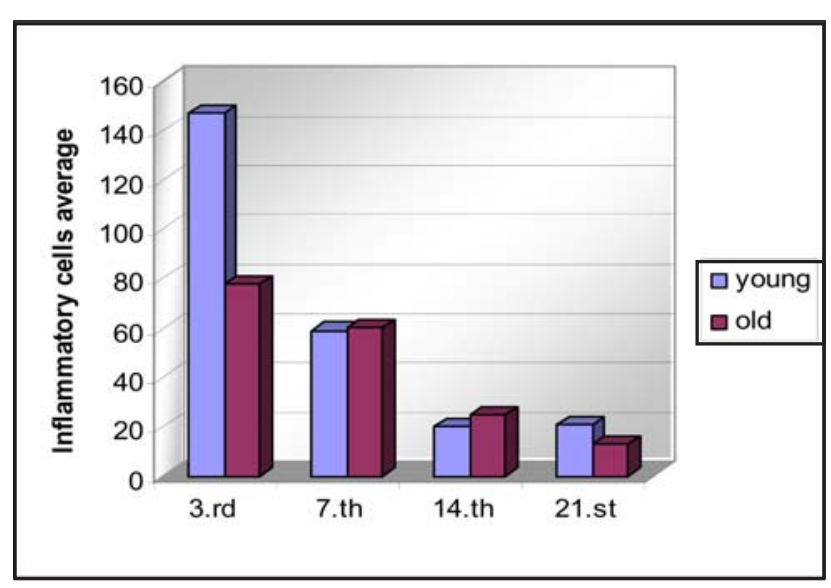

FIGURE 1 - Inflammatory cells in the cutaneous plane. On $3^{\text {rd }}$ day $p=0,0190$

The observation of vessels in the skin scar demonstrated that angiogenesis occurred at equal intensity in young and old rats on the $3^{\text {rd }}$ and $7^{\text {th }}$ days. On the $14^{\text {th }}$ day, angiogenesis was more intense in old animals ( $\mathrm{p}=0.0062$ ), again showing similar levels on the $21^{\text {st }}$ day.

A vessel count in three fields in the PMA scar showed that angiogenesis occurred at similar intensity in the two groups on the $3^{\text {rd }}$ and $7^{\text {th }}$ days. On the $14^{\text {th }}$ day it was more evident in the scars of old animals ( $p=0.0432$ ) (Figure 4) and on the $21^{\text {st }}$ day it was again similar in the two groups.

When three fields were examined in the histologic sections of skin scars stained with Sirius Red under polarized light and the mean percent area occupied by collagen was calculated, it was observed that the total collagen 


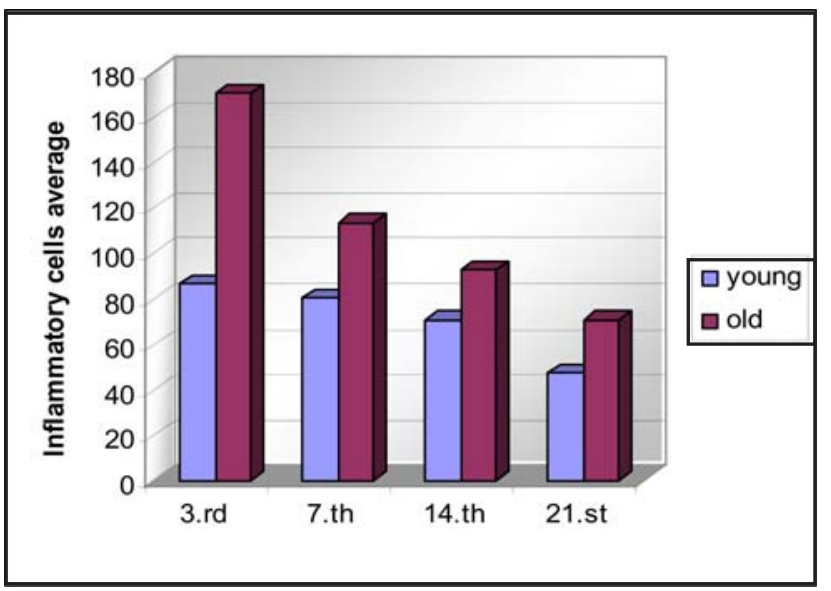

FIGURE 2 - Inflammatory cells in the PMA plane. On $3^{\text {rd }}$ day $\mathrm{p}=0,0060$

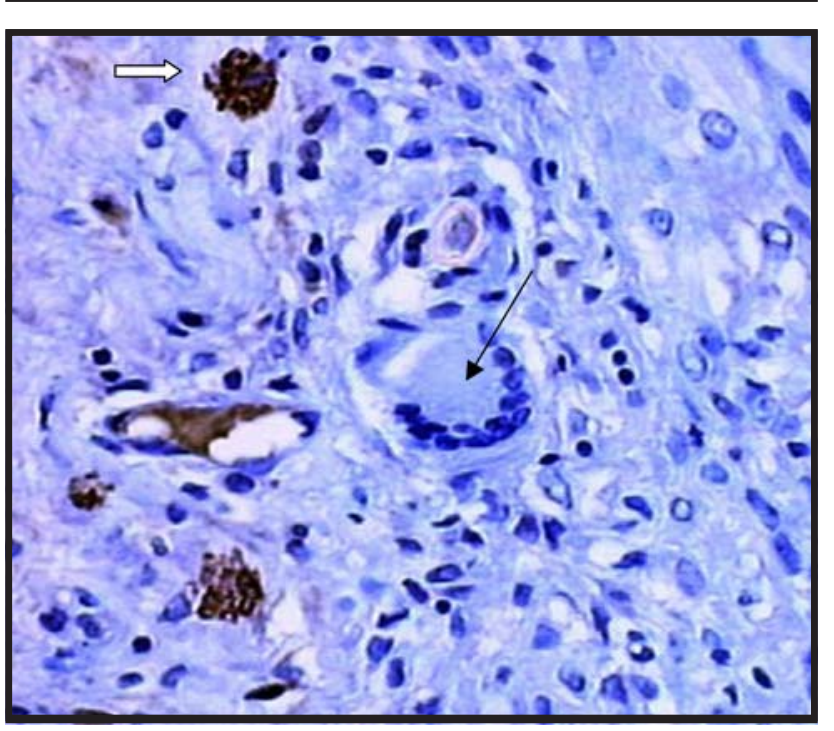

FIGURE 3 - Photomicrography of the PMA plane at the later time. It is possible to identify mast cells $(\Rightarrow)$ and foreign body giant cell $(\downarrow)$ ( LCA-100 X)

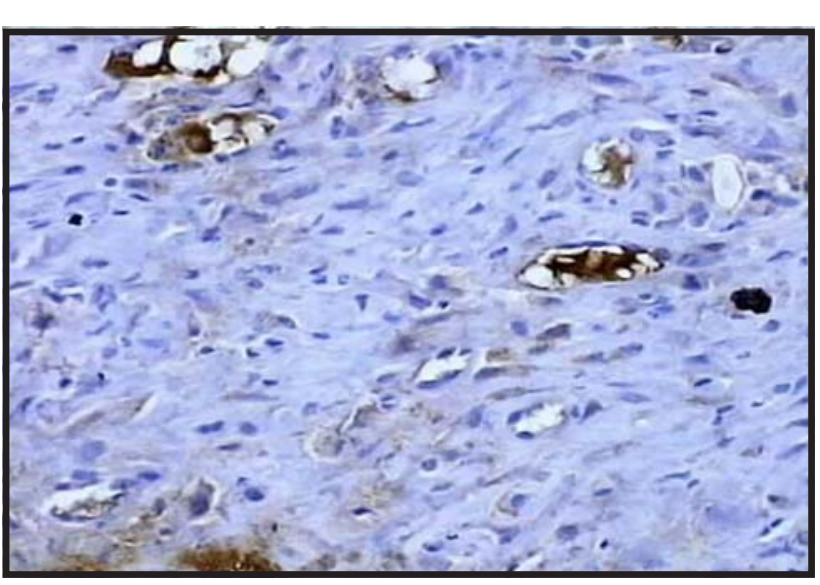

FIGURE 4 - Photomicrography of the PMA plane of the old animal with vessels (CD34-200 X) concentration was similar in young and old animals at all 4 time points studied $\left(\mathrm{p}_{3}=0.3399, \mathrm{p}_{7}=0.4340 . \mathrm{p}_{14}=0.0869\right.$, $\left.\mathrm{p}_{21}=0.3399\right)$. The concentration of collagen III represented by fine green fibers was similar in the two groups $\left(\mathrm{p}_{3}=0.1694\right.$, $\mathrm{p}_{7}=0.3541, \mathrm{p}_{14}=0.3479, \mathrm{p}_{21}=0.2676$ ), the same occurring with collagen I, represented by thick fibers stained orange and red. It was only on the $14^{\text {th }}$ day that more collagen I was detected in the scars of old animals $\left(\mathrm{p}_{3}=0.3341, \mathrm{p}_{7}=0.2572\right.$, $\left.\mathrm{p}_{14}=0.0250^{*}, \mathrm{p}_{21}=0.3068\right)$ (Figure 5 and 6).

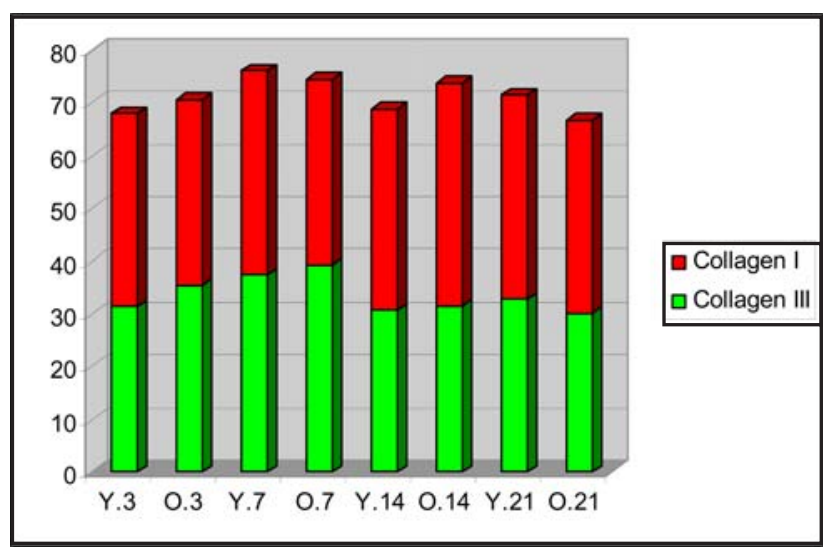

FIGURE 5 - Mean percent collagen content in histological sections obtained from the skin scars of young (Y) and old $(\mathrm{O})$ rats

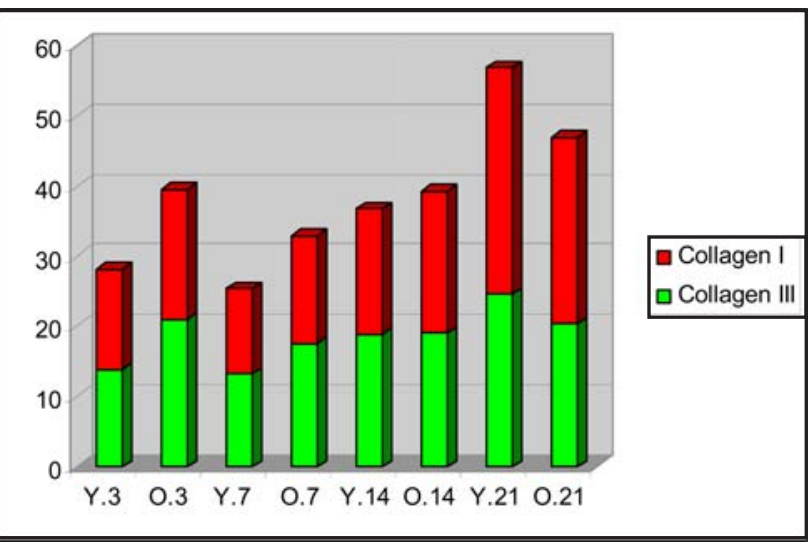

FIGURE 6 - Mean percent collagen content in histological sections obtained from the PMA plane of young $(\mathrm{Y})$ and old $(\mathrm{O})$ rats

\section{Discussion}

Before starting a critical analysis of the results obtained in the present study it is necessary to understand what we mean by "old". What is aging? The word "old" has a common meaning for everyone. The signs of aging are so evident that it is possible to estimate with some safety the age of the person observed by examining such signs, i.e., white hair, expression wrinkles, and curvature of the spine, among others.

Aging could be defined as a biological process that manifests as a continuous and systematic change of an individual, with death being the final result. It has the 
following characteristics: 1- it is deleterious, i.e., it reduces functional capacity; 2- it is progressive and gradual; 3 - it is intrinsic, i.e., it does not depend exclusively on the variation of environmental factors, and 4- it is universal, with all individuals being submitted to it in an irreversible manner ${ }^{21}$.

This process is common to all species although the life cycle is not the same for all. Thus, for example, man will be old at 80 years, dogs and sheep at 12 years, and pigs at 16 years. This clearly shows that longevity is associated with genetic inheritance, i.e., with nucleic acids, permitting us to state that man carries his potential life span at birth, although this potential will be influenced by the environment and the quality of life, including customs such as type of diet, physical activity, stress, type of work etc. Also to be considered are the diseases acquired during one's lifetime, some of them lethal.

Another question is chronological age, the parameter most commonly used to define an individual as old. However, chronological age is only one of the parameters, and others should be considered such as organic functions, sanity and the degree of physical dependence.

If we consider the potential for longevity to reside in the nucleic acids, with the improvement of preventive, diagnostic and therapeutic measures of medicine, the tendency is that the mean life span of man, which has increased over the last decades, will continue to escalate, with the presence of increasingly older patients.

When an elderly patient needs surgery it is necessary to keep in mind his general functional conditions and the way his recovery will occur, both in general terms and in terms of tissues and organs. Being old is not a synonym of being inoperable. Obviously the organs and systems of an elderly patient have suffered more or less severe modifications along the years and it is the surgeon's task to recognize them and to know how to handle them.

Many investigators have written about the care and the systemic complications of older patients. When a literature survey is conducted to find out what is available about tissue repair, it can be seen that many investigators write about skin repair, perhaps because of a concern with rejuvenation surgeries. However, few studies are available about the repair of the aponeurotic, muscular and even visceral planes.

In a clinical study, Lindstedt and Sandblom ${ }^{22}$ observed that the resistance of skin scars located on the forearm of healthy volunteers was lower in individuals older than 80 years. Leaming ${ }^{23}$ reported that, two weeks after induction, the scars of old mice were less resistant than those of young mice. Holm-Pedersen and Zederfeldt ${ }^{24}$ reported that the resistance of scars of the dorsal skin of old and young rats was identical on the $7^{\text {th }}$ and $14^{\text {th }}$ days, while on the $21^{\text {st }}$ day the scars of young rats had become more resistant.

Holm-Pedersen and Viidik ${ }^{25,26}$ observed that wounds made in the dorsum of young rats presented better mechanical properties, greater elasticity and greater capacity for energy absorption and therefore were more resistant than those made in the dorsum of old rats. Sussman ${ }^{27}$ studied the wounds made in the dorsum of rats. He removed the sutures after one week and reported that the resistance of the scars was identical in young and old animals between the $2^{\text {nd }}$ and $5^{\text {th }}$ week, whereas the resistance between the $5^{\text {th }}$ and $8^{\text {th }}$ week was higher in young rats and this difference persisted up to the $13^{\text {th }}$ week.

Quirinia and Viidik ${ }^{28}$ stated that skin wounds heal well both in young and old rats, with similar resistance on the $20^{\text {th }}$ day. In contrast, Swift et $\mathrm{al}^{17}$ reported that wounds made in the dorsum of old rats were less resistant.

It should be pointed out that in all the studies cited above the incisions were dorsal, whereas in the present study they were ventral (abdominal). In the current study, the skin scar did not offer any resistance in young or old animals on the $3^{\text {rd }}$ day, seemingly being held together by the suture. The gain in resistance on the $7^{\text {th }}$ day was nonsignificant since only one scar in young rats and one in old rats withstood some traction. In contrast, on the $14^{\text {th }}$ day the scars of young animals withstood mean tractions of $4.644 \pm 1.3939 \mathrm{~N}$ and those of old rats withstood tractions of $3.903 \pm 1.1611 \mathrm{~N}$. However, even though the skin wounds of young rats showed greater resistance, the difference was nonsignificant compared to old rats $(\mathrm{p}=0.1625)$. On the $21^{\text {st }}$ day the wounds of young rats withstood traction of $8.085 \pm$ $1.5547 \mathrm{~N}$ and the wounds of old rats withstood traction of $5.435 \pm 0.8585 \mathrm{~N}(\mathrm{p}=0.0029)$. Thus, the skin wounds of young animals were significantly more resistant than those of old rats only on the $21^{\text {st }}$ day.

Whereas literature reports are limited to the study of resistance of skin scars, the present study deals not only with the skin but also with all the planes of the abdominal wall, with special emphasis on the PMA, the plane considered to be the most important for the maintenance of the integrity of the abdominal wall and to be responsible for the occurrence of incisional hernias when it suffers faulty repair.

PMA scars did not present detectable resistance on the $3^{\text {rd }}$ day. At the remaining time points, the scars of old rats proved to be more resistant. The difference was not significant on the $7^{\text {th }}$ day but on the $14^{\text {th }}$ day the scars of young rats withstood, on average, $3.4650 \pm 0.6926 \mathrm{~N}$ and those of old rats withstood $5.3810 \pm 0.9680 \mathrm{~N}(\mathrm{p}=0.0005)$. On the $21^{\text {st }}$ day, the scars of young rats withstood $5.0408 \pm$ $1.3492 \mathrm{~N}$ and the scars of old rats withstood 7.1827 \pm 0.4017 $\mathrm{N}(\mathrm{p}=0.0023)$. Thus, the PMA scars of old rats were more resistant on the $14^{\text {th }}$ and $21^{\text {st }}$ days.

Investigators who studied skin healing in old individuals agree that reepithelialization is slower, that men are more affected than women, that the density of granular tissue is lower, that fibroblast migration is delayed, and that angiogenesis is normal in these subjects. There is no consensus about the inflammatory reaction, with some stating that it is delayed and less intense, and others stating that it is normal. There is also disagreement about the behavior of collagen, which is reported to be reduced by some and to be normal by others ${ }^{13,29-32}$.

Goodson and Hunt ${ }^{33}$ reported that the wounds of old rats healed more slowly than those of young rats. Lombard and Masse $^{34}$ observed a reduction of fibroblast migration and proliferative ability in the cutaneous tissue of old rats. Quirinia and Viidik ${ }^{28}$ monitored the healing of skin wounds in young and old rats and concluded that the process occurred in an identical manner in the two groups of animals. Ashcroft et $\mathrm{al}^{16}$ reported delayed reepithelialization in old rats on the $3^{\text {rd }}$ day, whereas on the $7^{\text {th }}$ day the 
reepithelialization of old rats was identical to that of young rats.

In the present study, general microscopic examination of histologic sections stained with hematoxylin-eosin revealed similar results for the skin wounds of young and old rats. Thus, we agree with Quirinia and Viidik ${ }^{28}$ when they state that the skin scars of young and old rats healed in a similar manner. It should be kept in mind that this is a qualitative analysis that might lad to imprecise conclusions. For this reason, the present investigation was accompanied by quantitative analyses which we shall discuss further on.

Qualitatively, the scars of the PMA plane evolved in an identical manner in young and old animals at all 4 time points studied. The musculature showed solution of continuity throughout the study period. At first, an important polymorphonuclear, macrophage and mast cell infiltrate and scarce granulation tissue were observed. On the $7^{\text {th }}$ day, a high concentration of fibroblasts and new vessels and abundant granulation tissue were present. On the $14^{\text {th }}$ day, lymphocytes were detected among the inflammatory cells mentioned. On the $21^{\text {st }}$ day, although the musculature continued to be discontinuous, a high concentration of collagen tissue could be seen on the inner and outer margins of the wound. We emphasize that mast cells were present in large numbers at all time points studied.

According to Ashcroft et $\mathrm{al}^{35}$ there are no systematic studies of the effects of aging on the inflammatory phase and little is known for sure. It is important to consider not only the effects of the altered cell response on the rate of repair, but also the influence of age on the kinetic change in matrix deposition. Polymorphonuclear cells are the first to appear and do not seem to suffer the influence of aging in terms of their numbers in scars ${ }^{36}$.

Kligman $^{30}$ reported that the migration of inflammatory cells occurring during the acute phase is delayed and less intense in old individuals. Kligman and Lavker ${ }^{31}$ consider the inflammatory reaction to be age dependent and reported that the number of mast cells decreases with aging. If these cells are involved in angiogenesis, it is to be expected that angiogenesis will be impaired. Holt et $\mathrm{al}^{13}$ declared that there is no difference in the number of inflammatory cells detected in young old and old individuals. In contrast, Gerstein et $\mathrm{al}^{37}$ stated that the inflammatory response in decreased or delayed in old individuals. Ashcroft et $\mathrm{al}^{38}$ observed that the inflammatory response quantified for monocytes/ macrophages and B lymphocytes presented a peak on the $3^{\text {rd }}$ day in young rats and on the $7^{\text {th }}$ day in old rats.

According to Pawsinska, Wroblewski and $\mathrm{Kaca}^{39}$, neutrophil chemotaxis is decreased in individuals older than 65 years.

Ashcroft et al $^{39}$ studied cell migration in vitro and detected an increased neutrophil response in old individuals with a delayed appearance of monocytes/macrophages and lymphocytes. The increased presence of proteinases in the wounds of old individuals may be related to increased neutrophil migration leading to fibronectin degradation and delayed healing ${ }^{40.41}$.

Macrophage function is reduced in old mice, with delayed repair ${ }^{42}$. Murine macrophages produce less TNF-a in old mice, with a reduction in phagocytosis ${ }^{43}$. The utilization of glucose by lymphocytes and macrophages decreases with age and this contributes to a decline in phagocytosis and cell proliferation ${ }^{44}$. Most authors have studied inflammatory cell migration in human volunteers and there is no agreement about the behavior of these cells with aging. Whereas some report delayed migration and a less intense reaction ${ }^{30,31,37}$, others consider these events to be similar to those observed in young individuals ${ }^{13,36}$ and still others state that cell migration is increased, particularly concerning neutrophils ${ }^{39}$.

In the present study, the mean number of cells per field examined was higher in young rats on the $3^{\text {rd }}$ day $(\mathrm{p}=0.0190)$. On the $7^{\text {th }}$ and $14^{\text {th }}$ days the concentration of inflammatory cells was similar in the skin wounds of young and old rats, and on the $21^{\text {st }}$ day, the number of cells tended to be higher in the wounds of young animals. However, the small number of samples examined at this time point may have impaired the analysis. It should be pointed out that mast cells were present at equal intensity in the two groups at all time points. Thus, we may state that the infiltration of inflammatory cells occurred earlier in young animals, but the concentration of these cells in the wounds of young and old animals became identical soon thereafter.

The infiltration of inflammatory cells on the PMA plane has not been a subject of interest to investigators. The results obtained in the present study showed that the concentration of inflammatory cells in the wounds of the PMA plane tended to be higher in old animals, although the difference was significant only on the $3^{\text {rd }}$ day $(p=0.0060)$. It would be interesting to increase the number of animals in the sample in order to reach a conclusion.

Boucek et $\mathrm{al}^{45}$, in a study of sponges implanted into human wounds for 4 months. observed that more collagen was present in older than in younger individuals, but that the collagen of older people was less soluble. This lower solubility was explained by Kao et $\mathrm{al}^{46}$ who stated that the extent of molecule cross-linking increases as a consequenc of aging. This confers greater heat stability to collagen, in addition to lower solubility and a reduced turnover rate. Viljanto ${ }^{47}$ left sponges in incisions made in human beings for the detection of collagen synthesis and observed that after 7 days, the older the patient the lower the quantity of collagen. Lovell et $\mathrm{al}^{48}$ reported that the proportion of collagen III was reduced to a varying extent from 65 years of age on in the skin removed from laparotomies at autopsy, and that the immunoreaction for type III increased with age.

Jones et $\mathrm{al}^{32}$ reported a greater accumulation of noncollagen proteins in elderly individuals, although their collagen synthesis was normal. In an in vitro study on the rate of collagen and proteoglycan synthesis in cells obtained from donors ranging from fetuses to individuals older than 80 years, Takeda et $\mathrm{al}^{49}$ observed a reduction of as much as $25 \%$ in the mRNA for collagen I and collagen III in older individuals. In contrast, according to HOLT et $\mathrm{al}^{13}$, aging did not affect collagen synthesis in human beings up to the $14^{\text {th }}$ day after sponge implantation in wounds, when the sponges were removedw, but the production of noncollagen proteins was reduced. Reed et $\mathrm{al}^{50}$ reported that human fibroblasts obtained from donors aged 26 to 92 years 
produced a similar quantity of mRNA for collagen I in response to TGF-â 1 . Lenhardt et al ${ }^{51}$ reported a decreased collagen deposition in the wounds of elderly men but not of elderly women. Kletsas et $\mathrm{al}^{20}$, in a study of fibroblast cultures, did not find any evidence of a relationship between age and a decline in the response to EGF, TNF-á and PDGF.

Thus, the picture emerging from investigations on human beings is confused. Some investigators state that older individuals synthesize less collagen while others state that they synthesize more collagen, and still others state that age does not affect synthesis. It seems, however, that the ability of fibroblasts to respond to stimuli is not modified.

Holm-Pedersen and Viidik ${ }^{25}$ stated that the rate of collagen maturation in the wounds of old rats is increased up to the $21^{\text {st }}$ day compared to the wounds of young rats. Platt and Ruhl ${ }^{52}$ implanted sponges into the subcutaneous network in incisions made in rats amd observed that the rate of proline $\mathrm{H}^{3}$ incorporation was lower in young rats.

Mollenhauer and Bayreuther ${ }^{53}$ observed increased fibroblast synthesis with age in culture of rat fibroblasts, with a direct relationship between age and collagen production. Lombard and Masse ${ }^{34}$ reported reduced migration and proliferative ability of fibroblasts obtained from cutaneous tissue of old rats. Martin et $\mathrm{al}^{54}$ reported that fibroblasts obtained from old pigs showed increased synthesis of fibronectin and collagen III. In a study on hamsters, Bruce and Deamond ${ }^{55}$ concluded that age is related to the proliferative ability or the function of fibroblasts, as well as to the production and organization of the extracellular matrix, which was progressively reduced in older animals. Mays et $\mathrm{al}^{56}$ reported that collagen synthesis is activated in old rats but that collagen degradation is also increased.

Grabovo $^{57}$ reported a reduced number of fibroblasts in wound repair in rats, although these cells showed increased functional activity. Ashcroft et $\mathrm{al}^{16}$ observed that collagen I and III concentration was reduced in old rats. Swift et al ${ }^{17}$ studied collagen synthesis in rats and observed that synthesis reached a maximum peak in young rats on the $7^{\text {th }}$ day of healing, as opposed to the $10^{\text {th }}$ day in old rats. These authors considered this to be simply a delay.

Analysis of the histologic sections of the skin wounds studied here showed that young and old rats concentrate collagen in a similar manner. The content of collagen III or immature collagen was practically identical in the wounds of young and old animals during the 21 days of follow-up. The concentration of mature or type I collagen was higher in old animals on the $14^{\text {th }}$ day. However, if we consider that this concentration was again similar on the $21^{\text {st }}$ day, we may propose that this was not a real value since mature collagen content differed from the mean in only one of the skin wounds of old animals on the $14^{\text {th }}$ day, possibly shifting the result in a small sample. On this basis, it would be better not to consider this value. A larger sample may confirm whether or not this result was valid. Thus, we may state that in the present study the synthesis and maturation of collagen in the skin wounds occurred in a similar manner in young and old animals.

Note that the amount of total, mature and immature collagen was similar in the two groups at all time points, although at the 2 earlier time point the skin wounds practically offered no resistance to the tensile strength test. Thus, we may assume that it is not only the amount of collagen present, but also its spatial arrangement, that is responsible for the resistance of the wound.

The study of PMA plane healing in terms of collagen concentration and maturation has not received thus far the attention it deserves. Researchers are more concerned about the cutaneous plane because of rejuvenation treatments. When they considered the PMA plane, they do so because they are concerned about the implantation and incorporation of prostheses for the repair of faults that occurred when there was some disorder that led to inadequate healing of this plane due to local or even systemic factors.

When we monitored the collagen gain curve on this plane we noted that the wounds of old animals presented more collagen than those of young animal on the $3^{\text {rd }}$ day ( $\mathrm{p}=0.0112$ ). On the $7^{\text {th }}$ and $14^{\text {th }}$ days the wounds of young rats started to concentrate more collagen although the wounds of old animals continued to present a higher collagen content even if this difference was not significant. It was only on the $21^{\text {st }}$ day that collagen concentration in the scars of young animals exceeded that in the scars of old animals $(p=0.0348)$. However, if deposition of young immature collagen was expected to be higher in young animals and to occur only because of a slower collagen degradation in the wounds of old animals, this was not the case. The higher collagen concentration was also due to this, but synthesis was found to be increased in the wound of old rats.

Mollenhauer and Bayreuther ${ }^{53}$ stated that the fibroblasts of old rats increase collagen synthesis and Martin et $\mathrm{al}^{54}$ reported that skin wounds of old pigs synthesized more collagen III. In the present study the PMA wounds of old rats always showed a higher content of collagen III than the wounds of young rats, although the difference was significant only on the $3^{\text {rd }}$ and $7^{\text {th }}$ days. On the $3^{\text {rd }}$ day the content of mature collagen was higher in the wounds of old animals $(\mathrm{p}=0.0268)$. This probably occurred at the expense of the remaining collagen. On the $21^{\text {st }}$ day the concentration of mature collagen was higher in the wounds of young animals $(\mathrm{p}=0.0035)$, demonstrating that maturation occurs more rapidly in these animals.

At this point, it is interesting to attempt to correlate collagen with resistance. On the $3^{\text {rd }}$ day, total collagen concentration was closely similar to that detected on the $7^{\text {th }}$ day. However, on the $3^{\text {rd }}$ day the scars did not offer detectable resistance, always rupturing along the line of the wound. It was as if they were kept together by the sutures. In contrast, on the $7^{\text {th }}$ day the wounds were able to withstand some tension even though their collagen content had not increased significantly. This may perhaps be justified by the fact that collagen improved it structural arrangement. The more mature the collagen, the larger the number ofcross-linkings ${ }^{58}$. The tensile strength of the wounds increases with time despite the reduction in synthesis, and this may reflect a structural modification of collagen bundles ${ }^{59}$. On the $14^{\text {th }}$ day, the scars of old animals were more resistant than those of young animals even though the scars of the latter had a higher collagen 
concentration. On the $21^{\text {st }}$ day, the scars of young rats had more collagen and were more resistant. It should be pointed out that, even with differences in collagen content and resistance, the number of macroscopic healing faults represented by the dehiscences was not significant.

With respect to reepithelialization, there seems to be a consensus that aging delays the process. Baker and Blair ${ }^{29}$ stated that wound reepithelialization is delayed in older individuals, but only in males. Orentreich and Salmanowitz ${ }^{60}$ reported that reepithelialization after facial dermo-abrasion occurred within 10 days in young individuals, within 15 days in middle-aged individuals, and within 21 days with elderly individuals.

Fatah and Ward ${ }^{61}$ reported that reepithelialization of skin donor areas occurred within 21 days in 95\% of the sample of young patients, as opposed to only $80 \%$ of the sample of elderly patients. The remaining $20 \%$ of the sample of older patients required 28 to 68 days for reepithelialization of the donor area. Holt et $\mathrm{al}^{13}$ again stated that the wounds of older people show slower reepithelialization.

Studies on animals have confirmed the data obtained in human studies. Cohen et $\mathrm{al}^{42}$ reported that young rats presented $50 \%$ of the wounds closed within 4.3 days, whereas old rats reached this percentage in 6.3 days $(\mathrm{p}<0.001)$. Ashcroft et $\mathrm{al}^{16}$, in a study on rats, reported that reepithelialization was slower in old animals during the first 3 days and that the process was similar for young and old animals thereafter.

Swift et $\mathrm{al}^{17}$ reported that reepithelialization occurred more rapidly in young mice, with $46 \%$ of the wounds being reepithelialized on the $2^{\text {nd }}$ day and $100 \%$ on the $5^{\text {th }}$ day. In contrast, reepithelialization was only $4 \%$ on the $2^{\text {nd }}$ day and $64 \%$ on the $5^{\text {th }}$ day in old mice. Only on the $10^{\text {th }}$ day did the lesions of old mice show full reepithelialization.

In the present study, when we analyzed the general aspects we stated that reepithelialization occurred in a similar manner in the two groups of animals. However, on order to confirm this result we decided to study cells with PCNApositive nuclei which show the protein cycle of the cell, expressing the G1 phase, reaching a maximum in the $S$ phase and continuing to show a detectable reduction in the G2 phase. It can be seen that the mean number of PCNApositive cells was similar in young and old animals at the 4 time points studied, demonstrating that cell replication occurred at the same rate and confirming the observation that reepithlialization occurred at the same rate in young and old animals.

Most investigators believe that aging reduces angiogenesis. According to Holm-Pedersen and Zederfeldt ${ }^{24}$, there is no difference in wound neovascularization between young and old rats. Yamaura and Matsuzawa ${ }^{62}$ observed that capillary growth rate was reduced in old rats.

Sobin et al $^{63}$ reported that acute cicatrization capillaries in old rats are PAS negative during the first 2 weeks but become positive between 4 and 8 weeks, whereas the capillaries of young rats continue to be negative throughout this period of time. The authors believe that this is due 0 increase in the glycosylation of the basement membrane proteins of new vessels in aged animals.
Reed et al ${ }^{15}$ observed similar angiogenesis in wounds of young and old rats on the 7 th and $21^{\text {st }}$ day, but lower angiogenesis in old rats on the $14^{\text {th }}$ day. According to these investigators, the delay in angiogenesis was probably associated with reduced TGF-beta ! and type I collagen expression. They concluded that the changes in the levels of growth factors and extracellular matrix proteins contributed to the delay in angiogenesis.

Rivard et $\mathrm{al}^{64}$ reported that development of new vessels was reduced in old rabbits.

Swift et al ${ }^{17}$, in a study on mice, observed that angiogenesis was significantly delayed in old animals and detected a similar decrease in fibroblast-derived angiogenic mediators (FGF-2) and of vascular endothelial growth factor (VEGF). According to these investigators, the decline in the production of angiogenic growth factors was probably responsible for the decline in endothelial responsiveness and the delay in angiogenesis.

In the present study, the mean number of vessels per fields in the skin wound was very small on the $3^{\text {rd }}$ day and increased on the $7^{\text {th }}$ day. However, the amount of vessels counted in the wounds of young and old animals was similar. Surprisingly, on the $14^{\text {th }}$ day, the mean number of vessels counted in the wounds of old animals was higher than that counted in the wounds of young animals $(p=0.0062)$. On the $21^{\text {st }}$ day, although the vessels were more numerous in the wounds of old animals, the difference was no longer significant. These results are the opposite of those reported by Reed et $\mathrm{al}^{15}$.

Few data are available in the literature about angiogenesis at this level of the abdominal wall. In the present experiment, the findings obtained for the cutaneous plane were repeated. The mean number of vessels per field was similar in the two groups on the $3^{\text {rd }}$ day and increased in both groups on the $7^{\text {th }}$ day. On the $14^{\text {th }}$ day it was significantly higher in the scars of old animals $(p=0.0432)$ and returned to similar levels in the two groups on the $21^{\text {st }}$ day.

Comparison of the results obtained with young and old animals with respect to skin wounds led us to conclude that the scar resistance of young animals was greater on the $21^{\text {st }}$ day, the inflammatory reaction was higher in the scars of young animals only on the 3rd day, the content of total and immature collagen was similar and only the content of mature collagen was higher in young animals on the $14^{\text {th }}$ day, the rate of reepithelialization was identical for the two groups. And angiogenesis was more intense in young animals on the $14^{\text {th }}$ day.

Comparison of the results obtained with young and old animals with respect to peritoneum-muscle-aponeurosis wounds showed that the scars of the old animals were more resistant on the $14^{\text {th }}$ and $21^{\text {st }}$ days, the inflammatory process tended to be more intense in the scars of old animals although the difference was significant only on the $3^{\text {rd }}$ day, collagen content was higher in the scars of young animals on the $3^{\text {rd }}$ day and in the scars of old animals on the $21^{\text {st }}$ day, immature collagen content was higher in the scars of young animals on the $3^{\text {rd }}$ day and in the scars of old animals on the $7^{\text {th }}$ day, mature collagen content was higher in old animals on the $3^{\text {rd }}$ day and in the scars of young animals on the $21^{\text {st }}$ 
day, and angiogenesis was more intense in the scars of old animals on the $14^{\text {th }}$ day.

\section{Conclusion}

Although there are some differences in the healing course between young and old animals, age, of itself, does not impair the healing of abdominal wall wounds in rats.

\section{References}

1. Reiss R, Deutsch AA, Nudelman I. Surgical problems in octogenarians: epidemiological analysis of 1083 consecutive admissions. World J Surg. 1992;16:1017-21.

2. Kinsella K. Dimensiones demográficas y de salud en America Latina y el Caribe. In: Péres AE, Galinsky D, Martínez FM, Salas AR, Ayéndez MS. La atención de los ancianos: un desafio para los años noventa. Washington DC, OPS, 1994. p.3-18.

3. Bufalari M, Ferri M, Lolli G, Fabri C, Bisacci R. La chirurgia generale nel paziente ottuagenario. Minerva Chir. 1996;51:383-8.

4. Montesani C, De Milito R, Chiappolone S, Narilli P, D’Amato A, Ribotta G. Critical evaluation of the anastomoses in large bowel surgery: experience gained in 533 cases. Hepatogastroenterology. 1992;39:304-8.

5. Greenburg AG, Salk RP, Pridham D. Influence of age on mortality of colon surgery. Am J Surg. 1985;150:65-70.

6. Conti A, Tonini V. Mortalità e morbilità postoperatoria negli ultraottantenni. Minerva Chir. 1991;46:867-73.

7. Lubin MF. Is age a risk factor for surgery? Med Cl North Am. 1993; 77:327-33.

8. Hirsch $\mathrm{CH}$. When your patients need surgery: weighing risks versus benefits. Geriatrics. 1995;50:26-31.

9. Souza Filho ZA. Avaliação do risco cirúrgico em octogenários. [Tese]. Faculdade de Medicina da Pontifícia Universidade Católica do Paraná; 2000.

10. Mendoza CB, Postlethwait RW, Johnson WD. Incidence of wound disruption following operation. Arch Surg. 1970;101:396-8.

11. Riou JP, Cohen JR, Johnson H Jr. Factors influencing wound dehiscence. Am J Surg. 1992;163:324-30.

12. Gilchrest BA. In vitro assessment of keratinocyte aging. J Invest Dermatol. 1983;81:184s-9s.

13. Holt DR, Kirk SJ, Regan MC, Hurson M, Lindblad WJ, Barbul A. Effect of age on wound healing in healthy human beings. Surgery. 1992;112:293-8.

14. Morris GF, Matheus MB. Regulation of proliferating cell nuclear antigen during the cell cycle. J Biol Chem. 1989;264:13856-64.

15. Reed MJ, Corsa A, Pendergrass W, Penn P, Sage EH, Abrass IB. Neovascularization in aged mice: delayed angiogenesis is coincident with decreased levels of transforming growth factor beta 1 and type I collagen. Am J Pathol. 1998;152:113-23.

16. Aschcroft GS, Herrick SE, Tarnuzzer RW, Horan Ma, Schultz GS, Ferguson MW. Human ageing impairs injuryinduced in vivo expression of tissue inhibitor of matrix matalloproteinases (TIMP)-1 and -2 proteins and mRNA. J Pathol. 1997;183:169-76.

17. Swift ME, Kleimann HK, DiPietro LA. Impaired wound repair and delayed angiogenesis in aged mice. Lab Invest.
1999;79:1479-93.

18. Cristofallo VJ, Pignolo RJ. Replicative senescence of human fibroblast like cells in culture. Physiol Rev. 1993;73:617-38.

19. Freedland M, Karmiol S, Rodriguez J, Normolle D, Smith D Jr, Gamer W. Fibroblast responses to cytokines are maintained during aging. Ann Plast Surg. 1995;35:290-6.

20. Kletsas D, Pratsinis H, Zervolea I, Handris P, Sevaslidou E, Ottaviani E, Stathakos D. Fibroblast responses to exogenous and autocrine growth factors relevant to tissue repair: the effect of aging. Ann NY Acad Sci. 2000;908:155-66.

21. Nagy I, Totàro EA, Pisanti FA. Le basi citobiologiche dell'invecchiamento. Padova: Nuova Libreria; 1988. p. 2-3.

22. Lindstedt E, Sandblom P. Wound healing in man: tensile strength of healing wounds in some patient groups. Ann Surg. 1975;181:842-6.

23. Leaming DB. The influence of age on wound healing. J Surg Res. 1963;3:43-7.

24. Holm-Pedersen P, Zederfeldt B. Strength development of skin incisions in young and old rats. Scand J Plast Reconstr Surg. 1971;5:7-12.

25. Holm-Pedersen P, Viidik A. Maturation of collagen in healing wounds in young and old rats. Scand J Plast Reconstr Surg. 1972;6:16-23.

26. Holm-Pedersen P, Viidik A. Tensile properties and morphology of healing wounds in young and old rats. Scand J Plast Reconstr Surg. 1972;6:24-35.

27. Sussmann MD. Aging of connective tissue: physical properties of healing wounds in young and old rats. Am J Physiol. 1973;224:1167-71.

28. Quirinia A, Viidik A. The influence of age on the healing of normal and ischemic incisional skin wounds. Mec Ageing Dev. 1991;58:221-32.

29. Baker H, Blair CP. Cell replacement in the human stratum corneum in old age. Br J Dermatol. 1968;80:367-72.

30. Kligman AM. Perspectives and problems in cutaneous gerontology. J Invest Dermatol. 1979;73:39-46.

31. Kligman AM, Lavker RM. Cutaneous aging: the differences between intrinsic ageing. .J Cutan Ageing Cosmetol Dermatol. 1988;1:5-12.

32. Jones PL, Millman A. Wound healing and the aged patient. Nurs Clin North Am. 1990;25:263-77.

33. Goodson WH, Hunt TK. Wound healing and aging. J Invest Dermatol. 1979;73:88-91.

34. Lombard N, Masse R. Effect of in vivo ageing on the growth of rat fibroblasts in cells from cutaneous explants Royal Soc Sci Biol. 1987;181:267-73.

35. Aschcroft GS, Horan MA, Ferguson MWJ. The effects of ageing on cutaneous wound healing in mammals. $\mathrm{J}$ Anat. 1995;187:1-26

36. Danon D, Kowatch MA, Roth GS. Promotion of wound repair in old mice by local injection of macrophages. Proc Natl Acad Sci. 1989;86:2018-20.

37. Gerstein AD, Phillips TJ, Rogers GS, Gilchrest BA. Wound healing and aging. Dermatol Clin. 1993;11:749-57.

38. Aschcroft GS, Horan MA, Ferguson MWJ. Aging is associated with reduced deposition of specific extracellular matrix components, an upregulation of angiogenesis, and an altered inflammatory response in a murine incisional wound healing model. J Invest Dermatol. 
1997;108:430-7.

39. Aschcroft GS, Horan MA, Ferguson MWJ. Aging alters the inflammatory and endotelial cell adhesión molecule profiles during human cutaneous wound healing. Lab Invest. 1998;78:47-58.

40. Aschcroft GS, Horan MA, Ferguson MWJ. The effects of ageing on wound healing: immunolocalisation of growth factors and their receptors in a murine incisional model. J Anat. 1997;190:351-65.

41. Aschcroft GS, Kielty CK, Horan MA, Ferguson MWJ. Age-related changes in the temporal and spatial distributions of fibrillin and elastin mRNAs and proteins in acute cutaneous wounds of healthy humans. J Pathol. 1997;183:8-89.

42. Cohen BJ, Danon D, Roth GS. Wound repair in mice as influenced by age and antimacrophage serum. J Gerontol. 1987;42:295-301.

43. Higashimoto Y, Fukuchi Y, Shimada Y, Ishida K, Ohata $\mathrm{M}$, Furuse T. The effects of aging on the function of alveolar macrophages in mice. Mec Ageing Develop. 1993;69:207-17.

44. Costa Rosa LFBP, Almeida AF, Safi DA, Curi R. Metabolic and functional changes in lymphocytes and macrophages as induced by ageing. Physiol Behav. 1993;53:651-6.

45. Boucek RJ, Noble NL, Kao K-Yt, Elden HR. The effects of age, sex, and race upon the acetic acid fractions of collagen (human-biopsy-connective tissue). J Gerontol. 1958;13:2-9.

46. Kao K-YT, Hilker DM, McGavack TH. Connective tissue. IV. Synthesis and turnover of proteins in tissues of rats. Proc Soc Exp Biol Med. 1961;106:121-4.

47. Viljanto JA. A sponge implant method for testing connective tissue regeneration in surgical patients. Acta Chir Scand. 1969;135:297-300.

48. Lovell CR, Smolenski KA, Duance VC, light ND, Young S, Dyson M. Type I and III collagen content and fibre distribution in normal human skin during ageing. Br J Dermatol. 1987;117:419-28.

49. Takeda K, Gosiewska A, Peterkofsky B. Similar, but not identical, modulation of expression of extracellular matrix components during in vitro and in vivo aging of human skin fibroblasts. J Cell Physiol. 1992;153:450-9.

50. Reed MJ, Vernon RB, Abrass IB, Sage EH. TGF-beta 1 induces the expression of type I collagen and SPARC, and enhances contraction of collagen gels, by fibroblasts from young and aged donors. J Cell Physiol. 1994;158:169-79.

51. Lenhardt R, Hopf HW, Marker E, Okça O, Kurz A, Scheuenstuhl H, Sessler DI. Perioperative collagen deposition in elderly and young men and women. Arch Surg. 2000;135:71-4.

52. Platt D, Ruhl W. An age-dependent determination of lysosomal enzyme activities, as well as the measurements of the incorporation of 14-C proline and 14-C-glucosamine in a subcutaneously implanted polyether sponge. Gerontology. 1972;18:96-112.

53. Mollenhauer J, Bayreuther K. Donor-age-related changes in the morphology, growth potential, and collagen biosynthesis in rat fibroblast subpopulations in vitro. Differentiation. 1986;32:165-72.

54. Martin M, el Nabout R, Lafuma C, Crechet F, Remy J. Fibronectin and collagen gene expression during in vitro ageing of pig skin fibroblasts. Exp Cell Res. 1990;191:8-13.

55. Bruce SA, Deamond SF. Longitudinal study of in vivo wound repair and in vitro cellular senescence of dermal fibroblasts. Exp Gerontol. 1991;26:17-27.

56. Mays PK, McAnulty RJ, Campa JS, Laurent GJ. Agerelated changes in collagen synthesis and degradation in rat tissues. Biochem J. 1991;276:307-13.

57. Grabovo AN. Morphofunctional features of fibroblasts in wound healing in old age. Arkh Patol. 1995;57:35-8.

58. Hendriks T, Mastboom WJB. Healing of experimental intestinal anastomoses: parameters for repair. Dis Colon Rectum. 1990;33:891-901.

59. Doillon CJ, Dunn MG, Bender E, Silver FH. Collagen fiber formation in repair tissue: development of strength and toughness. Col Rel Res. 1985;5:481-92.

60. Orentreich N, Salmanowitz VJ. Levels of biological functions with aging. Trans NY Acad Sci. 1969;2:992-1012.

61. Fatah MF, Ward CM. The morbidity of split-skin graft donor sites in the elderly: the case for mesh-grafting the donor site. Br J Plast Surg. 1984;37:184-90.

62. Yamaura H, Matsuzawa T. Decrease in capillary growth during aging. Exp Gerontol. 1980;15:145-50.

63. Sobin SS, Bernick S, Ballard KW. Acute wound repair in an aged animals: a model for accelerated aging of the microvasculature. J Gerontol. 1992;47:121-5.

64. Rivard A, Fabre J, Silver M, Chen D, Murohara T, Kearney M, Magner M, Asahara T, Isner JM. Age-dependent impairment of angiogenesis. Circulation. 1999;99:111-20.

\author{
Correspondence: \\ Maria de Lourdes Pessole Biondo-Simões \\ Rua Ari José Valle, 1987, Santa Felicidade \\ CEP 82030-000. Curitiba-Paraná \\ Telefone (fax): 0XX41.297.43.59 \\ e-mail: biondo@avalon.sul.com.br
}

Conflict of interest: none Financial source: none

Received: 10/6/2004

Revised: $11 / 28 / 2004$

Aproved: 12/29/2004

\section{How to cite this article:}

Biondo-Simões ML, Terranova O, Ioshii SO, Borsato KS, Weingärtner J, Nogueira G, Longhi P. Effects of aging on abdominal wall healing in rats. Acta Cir Bras. [serial online] 2005 Mar-Apr;20(2). Available from URL: $\underline{\text { http://www.scielo.br/acb }}$ 